\title{
QUALITY SECONDARY SCHOOL ADMINISTRATION AND ECONOMIC DEVELOPMENT OF CROSS RIVER STATE
}

\author{
U. F. Mbon, N. N. Ukpong, J. A. Ekpenyong \\ Department of Educational Administration and Planning, Faculty of Education \\ University of Calabar, Nigeria
}

\begin{abstract}
The study aimed at finding out the relationship between quality secondary school administration and economic development of Cross River State. Survey research design was adopted for the study. The population of the study comprised 232 Principals from the 232 public secondary schools in the three Educational Zones in Cross River State. The 232 principals were purposively used as sample for the study. Three null hypotheses were formulated and tested in the study. The instrument for data collection was a structured questionnaire titled "Quality Secondary school Administration and Economic Development Questionnaire QSSAEDQ). The instrument was subjected to face validity and reliability test using Test-Retest method and was found reliable at 0.75 r_value. Pearson Product Moment correlation Statistics (r) was used for data analysis at 0.05 level of significance. Result obtained revealed that there is a significant relationship between Facilities administration, student personnel administration, knowledge management and economic development in Nigeria. Based on this result, it was recommended that school heads should ensure effective administration of school facilities, student personnel, as well as efficient knowledge management, to attain secondary Education goals, which would engender economic development of the state.
\end{abstract}

KEYWORDS: Educational administration, quality, economic development, school facilities, student personnel, knowledge management.

\section{INTRODUCTION}

The global trend in knowledge explosion has placed large demands on developing countries to redesign their educational system to meet the world's competitive benchmark for knowledge creation, knowledge utilization and knowledge reconstruction. The world today is characterized by knowledge economies, whereby the development of any society is practically dependent on the level of knowledge acquired and utilized in the economy. This espouses the fact that education is the driving force that propels the development of modern societies. This has been the rationale and the driving force behind the strife by modern societies, to have a functional educational system that fast tract the acquisition and accumulation of practical knowledge and skills for rapid economic growth and development. The need for quality administration in the educational system of Nigeria is quite obvious. There is general concern about standard of education in Nigeria, which emanates from the fact that the level of performance of students is dwindling with the passage of time (Arong \& Ogbadu, 2010). Adelabu (2013) lamented that Nigerians have sacrificed quality education on the altar of quantity and mass education. Arong and Ogbadu (2010) declared that there is a general outcry that the standards of education are falling and morals flagging. The above expressions are clear indications of poor administration of Nigerian schools. No country can attain any meaningful development when the educational system is not well administered.

Nwankwo in Okon (2004) defines educational administration as the systematic arrangement of human and material resources and programmes that are available for education, and carefully using them systematically within defined guidelines or policies to achieve educational goals. Akpan, Okon and Ebuara (2015) define educational administration as the process of providing control within the educational system in the way of coordinating activities and making decisions that would lead to the attainment of the school goals and objectives which are effective teaching and learning. It implies that the success of any education system revolves around its administration. Hence quality education, which is the necessary and sufficient condition for economic development, can only be 


\section{International Journal of Engineering Applied Sciences and Technology, 2019 Vol. 4, Issue 5, ISSN No. 2455-2143, Pages 541-548 \\ Published Online September 2019 in IJEAST (http://www.ijeast.com)}

effectuated when there is quality educational administration in Nigeria.

Babalola (2007) explained that quality is most often defined as "fitness to purpose in relation to the user and customer needs". Stressing further, he maintained that quality can also be taken to mean that the product conforms to standards, specifications or requirements". Bamisaiye in Gbenu (2012) defined it as the sum of composite of the properties inherent in a material or product. In line with the above definitions, quality educational administration would mean the control of schools and educational resources in line with current needs of the society. As pointed out by Olaniyonu, Adekoya and Gbenu, (2008) that the educational standards set for schools must be challenging to meet the needs of the students and the society.

The focus of the entire world has shifted from mere economic growth, to economic development where the concern is how to limit the poverty gap by promoting a production-based economy, where greater chunk of the inhabitants are able to produce goods and services through the acquisition of practical knowledge and skills. Agba (1994) opined that economic development is a more subtle concept that relates to citizen's attitudes and the institutional arrangement for the performance of the major activities in the economy. In the words of Nafziger (2006), Economic development refers to economic growth accompanied by changes in output distribution and economic structure. These changes may include an improvement in the material well-being of the poorer half of the population; a decline in agriculture's share of GNP and a corresponding increase in the GNP share of industry and services; an increase in the education and skills of the labor force; and substantial technical advances originating within the country. From the above, it behooves that economic development can only be attained through quality and practical education which is only achievable when there is quality school administration in the country.

Secondary education occupies a strategic position in the educational sector, it bridges the gap between the primary and tertiary level of education in Nigeria. The broad goals of secondary education are to prepare individuals for useful living and for higher education, which is designed to produce high level manpower for the development of the country (FRN, 2004). It is clear from here that secondary education holds the key to the effective functioning and the wellbeing of individuals in the society, as well as ensure the success and prosperity of higher education, which the hub of manpower or human capital production. There is no doubt that secondary education in Nigeria has not achieved stated goals. Gbenu (2012) declared that the state of secondary education in Nigeria largely explains the high level of underdevelopment or low rate of development in the country. He explains that Schools/structures are dilapidated, infrastructure have collapsed, population is increasing, teacher supply and quality are declining, poor method of ensuring quality within the education industry.

Williams (2004) lamented gloomily that "what is of greatest concern is that most curricula offerings are not current. Most learning is paper and pencil work. There is very little practical hands on learning in our schools". It is also noted that there is inadequate or poor student personnel services in secondary schools for effective learning. Duffy in Ejionume (2010) and Swartz, Huut and Reilly in Ogbuji (2009) in their separate opinions, observed that student personnel is an administrative task areas that is critical to the effective operation of any school system. The worse and a more unappealing situation is the issue of poor knowledge management, whereby the curricular offered in schools, have little or no practical linkages with the knowledge needed for societal development as stipulated in the National Policy on Education. It is the function of educational administrators to ensure that there are adequate and functional school facilities, effective student personnel services to enhance students' learning and above all, to ensure that the skills and knowledge provided in schools have a strong connection with the needs of the society.

Amachukwu and Ololube (2005) submitted that functional school plant enhances good delivery of educational services required to promote education of learners, a key aspect of the school goal. Oyesola (2007) reported that the main objective of school plants management is to satisfy educational goals which have been pre-determined, that better planned school plant maintenance practice will enhance better school programmes and the attainment of the goals of the school. Ajayi (2007) asserts that high level of students' performance role will be defective where school plants are not properly managed. A study conducted by Sani (2007) on the relationship between school plant construction, utilization, maintenance and school effectiveness in Kebbi State secondary schools in Nigeria. The analysis of data obtained revealed that there was a significant positive and high relationship between school plant maintenance and school goal attainment. According to Asiabaka (2008); Olaniyan and Israel (2013), physical environment of any school is a major determinant factor that enhances attainment of school goal. From the above, it is clear that quality 


\section{International Journal of Engineering Applied Sciences and Technology, 2019 \\ Vol. 4, Issue 5, ISSN No. 2455-2143, Pages 541-548 \\ Published Online September 2019 in IJEAST (http://www.ijeast.com)}

school facilities administration is one of the sole determinants of school goal attainment, which is a factor of economic development of any nation. Aloga (2014) asserted from her study that when the school physical plant is well planned it will not only enhance good teaching practice but will also facilitate and stimulate leaning. It will also be correct to assert that school plant represents the empirical relevance of the totality of the school environment for the realization of the school business which apparently is the teaching and learning to realize the social educational goals, which would boost economic development.

A study carried out by Chidobi (2015), on "management of student personnel service in public secondary schools in Enugu Education Zone for sustainability of quality, human resources for national development". The result of the study revealed that proper management of student personnel services such as admission service among others, at the secondary school level has a positive influence on realization of sustainable future, vis-à-vis the attainment of school goals. Ehiane (2014) investigated discipline and academic performance in selected secondary schools in Lagos, Nigeria. The findings of the study clearly showed that effective school discipline has a great influence on students' behavior and thus affects their general academic performances, as well as the attainment of the general goal of the school system which is effective teaching and learning. Hence, effective school discipline was encouraged in the area. Modo, Sanni, Uwah and Mogbo (2013) stated that guidance and counselling is one of the educational services that prompted the effectiveness of the educational system for goals attainment and guiding learners through the learning process. Zahyah, Yusuf and Muhajir (2016) examined the nexus between students personnel services (health, guidance and library services) and academic achievement in secondary schools. The results of the study reported the existence of a relationship between guidance and counseling service and students' academic achievement among others. It was conducted that guidance and counseling service, among others, is an indispensable service and is very crucial to the attainment of secondary education goals, as well as the national goals of the nation. It implies that quality student personnel administration has a significant influence on the success of schools, which is akin to economic development.

Jarboe (2001) opined that the ability of a locality to supply a company's need for information and knowledge assets has become paramount in economic development. Stating further, he maintained that knowledge management has three objective domains; creation of knowledge repositories, improving knowledge access, enhancing the knowledge environment and management of knowledge as an asset. Bratti (2004) designed a relationship model between economic growth and human capital accumulation. The model was developed on the basis of countries at different phases of development. The results showed that there is positive direct relationship between education level and production level. This leads to enhancing the consideration of knowledge as a production function in competitive business scenario.

Bhullar and Kaur(2014) submitted that knowledge and ideas have been emerged as key drivers for the economic growth in current scenario. They found out in their study that firm specific, Sector specific and General knowledge are the three forms of knowledge that play a significant role in economic growth, and that the well qualified human capital has positive impact on economic growth through total factor productivity. Kahreh (2011) in his study, asserted that the increased prominence of knowledge related economics from the beginning of the 1990s have coexisted with the development of the new view on business strategy that emphasizes resource efficiency rather than the generally accepted competitive forces. According to him, in the eeconomy era, for any country to achieve and sustain the competitive advantage, the implementation of strategic knowledge management (SKM) is undeniable. He explained further that through knowledge driven reconfiguration, integration and innovation, organizational and institutional competencies are gained in the economy. The above review stipulates the fact that linking school experiences to the needs of the society would boost organizational and institutional performance, which would enhance economic and development of the country.

\section{STATEMENT OF THE PROBLEM}

The struggle for a steady progression in economic prosperity and the strife to narrow the poverty gap in the society has been the pre-occupation of every developing economy of which Nigeria is not an exception. There have been several educational policy designs put in place in Nigeria from independence till date, all in an attempt to increase the literacy rate of the people, reduce poverty rate by promoting skilledbased economy, reduce social unrest by engaging the youths in productive ventures, and above all, increase the general standard of living of the Nigerian society. Despite these aggressive educational policies designed to boost the level of social wellbeing and economic 


\section{International Journal of Engineering Applied Sciences and Technology, 2019 \\ Vol. 4, Issue 5, ISSN No. 2455-2143, Pages 541-548 \\ Published Online September 2019 in IJEAST (http://www.ijeast.com)}

progression of the nation, Nigeria is still operating at a rate far behind the global benchmark for economic development: no practical skills for industrial productivity, high level of illiteracy, high level of social unrest and insecurity, high cost of living, high rate of poverty and the general fall in the standard of living of the people. These are clear evidences of economic retardation of the country.

This situation is worse in Cross River State where there are high rates of poverty, social upheaval, cultism, non-existence of industries, existence of graduates with no practical skills and the general low standard of living. It is an explicit fact that no society can grow above its level of education. This expresses that fact that there is a problem with educational administration in Nigeria, specifically in Cross River State. Education, especially at the secondary school level, should be able to equip citizens with practical skills needed for high productivity in the economy, prepare them adequately for higher learning and inculcate in them values and moral standards that would promote peace and security for economic progression. It is on this premise that it becomes pertinent to raise the question: "what is the relationship between quality secondary school administration and economic development of Cross River State?"

\section{PURPOSE OF THE STUDY}

The general purpose of the study is to investigate the relationship between quality secondary school administration and economic development of Cross River State. Specifically, the study is designed to ascertain the relationship between;

1. School facilities administration and economic development.

2. Student personnel administration and economic development.

3. Knowledge management and economic development.

\section{RESEARCH QUESTIONS}

The following questions were posed to direct the study;

1. How does school facilities administration relate to economic development?

2. To what extend does student personnel administration with economic development?
3. What is the relationship between knowledge management and economic development?

\section{STATEMENT OF HYPOTHESES}

The following hypotheses were formulated to guide the study;

1. School facilities administration does not have any significant relationship with economic development.

2. Student personnel administration does not have any significant relationship with economic development.

3. There is no significant relationship between knowledge management and economic development.

\section{METHODOLOGY}

The research design adopted for the study was the survey research design. The population of the study comprised of all principals in the two hundred and fifty one (251) secondary schools in the three (3) educational zones in Cross River State. The entire population of the study was purposively used as sample for the study. Three (3) hypotheses were formulated and tested in the study. The instrument used for data collection was a 4-point Likert questionnaire titled; "Quality Secondary school Administration and Economic Development Questionnaire (QSSAEDQ). The questionnaire was divided into two sections; section $\mathrm{A}$ and section $\mathrm{B}$. section A was designed to measure the sub-variables of quality secondary school administration, while section $\mathrm{B}$ consists of items designed to measured economic development focusing on indices like the level acquisition of practical skills among students and the relevance of school programmes to the need of society. The instrument was subjected to face validity and reliability test using Test-Retest method and was found reliable at $0.75 \mathrm{r}$-value. Paerson Product Moment correlation Statistics (r) was used for data analysis at 0.05 level of significance.

\section{RESULT}

\section{Hypothesis 1:}

School facilities administration does not have any significant relationship with economic development. The result analysis is presented in Table 1. 


\section{International Journal of Engineering Applied Sciences and Technology, 2019 \\ Vol. 4, Issue 5, ISSN No. 2455-2143, Pages 541-548 \\ Published Online September 2019 in IJEAST (http://www.ijeast.com)}

TABLE 1

Pearson product moment correlation analysis of the relationship between school facilities administration and economic development.

$$
\mathrm{N}=251
$$

\begin{tabular}{lllll}
\hline Variables & $\sum \mathrm{X}$ & $\sum \mathrm{X}^{2}$ & $\sum \mathrm{XY}$ & r.cal \\
& $\sum \mathrm{Y}$ & $\sum \mathrm{Y}^{2}$ & & \\
\hline School facilities administration (X) & 788 & 1431 & & \\
& & & 2410 & 0.559 \\
Economic development (Y) & 621 & 1203 & & \\
\hline
\end{tabular}

Significant at 0.05 alpha level. $\mathrm{df}=249$. r.crit $=0.113$

The result of the analysis in table 1 shows that the calculated r-value of 0.559 is greater than the critical $r-$ value of 0.133 at 0.05 level of significance and 249 degrees of freedom. Based on this result, the null hypothesis is rejected and the alternative hypothesis accepted. This means that there is a significant relationship between school facilities administration and economic development.

\section{TABLE 2}

Pearson product moment correlation analysis of the relationship between student personnel administration and economic development.

$$
\mathrm{N}=251
$$

\begin{tabular}{lllll}
\hline Variables & $\sum \mathrm{X}$ & $\sum \mathrm{X}^{2}$ & $\sum \mathrm{XY}$ & r.cal \\
& $\sum \mathrm{Y}$ & $\sum \mathrm{Y}^{2}$ & & \\
\hline Student personnel administration. (X) & 688 & 1351 & & \\
& & & 2158 & $0.754^{*}$ \\
Economic development. (Y) & 621 & 1203 & & \\
\hline
\end{tabular}

Significant at 0.05 alpha level. $\mathrm{df}=249$. r.crit 0.113 .

The result of the analysis indicates that the calculated r-value of 0.754 is greater the critical rvalue of 0.113 at 0.05 level of significance and 249 degrees of freedom. Based on this result, the null hypothesis is rejected and the alternative hypothesis accepted. This implies that there is a significant
Hypothesis 2:

Student personnel administration does not have any significant relationship with economic development. The result of the data is shown in Table 2 .

TABLE 3 


\section{International Journal of Engineering Applied Sciences and Technology, 2019 \\ Vol. 4, Issue 5, ISSN No. 2455-2143, Pages 541-548 \\ Published Online September 2019 in IJEAST (http://www.ijeast.com)}

Pearson product moment correlation analysis of the relationship between knowledge management and economic development.

$$
\mathrm{N}=251
$$

\begin{tabular}{lllll}
\hline Variables & $\sum \mathrm{X}$ & $\sum \mathrm{X}^{2}$ & $\sum \mathrm{XY}$ & r.cal \\
& $\sum \mathrm{Y}$ & $\sum \mathrm{Y}^{2}$ & & \\
\hline Knowledge management. (X) & 723 & 1400 & & \\
& & & 2345 & 0.846 \\
Economic development. (Y) & 621 & 1203 & &
\end{tabular}

Significant at 0.05 alpha level. $\mathrm{df}=249$. r.crit 0.113 .

The result of the analysis in table 3 shows that the calculated $\mathrm{r}$-value of 0.846 is greater than the critical r-value of 0.113 at 0.05 level of significance and 249 degrees of freedom. Based on this result, the null hypothesis is rejected while the alternative hypothesis is accepted. This means that there is a relationship between knowledge management and economic development.

\section{DISCUSSION OF FINDINGS}

The result of the first hypothesis revealed that school facilities administration has a significant relationship with economic development of Cross River State. This result is supported by Sani (2007). He conducted a study on the relationship between school plant construction, utilization, maintenance and school effectiveness in Kebbi State secondary schools in Nigeria and found out that there is a significant positive and high relationship between school plant maintenance and school goal attainment. Affirming further, Asiabaka (2008); Olaniyan and Israel (2013) maintained that the physical environment of any school is a major determinant factor that enhances attainment of school goal. From here, it means that quality school facilities administration is one of the sole determinants of school goal attainment, which is a factor of economic development of any nation.

The result of the second hypothesis showed that there is a significant relationship between student personnel administration and economic development of Cross River State. This is in line with the findings of Chidobi (2015) in his study on "management of student personnel service in public secondary schools in Enugu Education Zone for sustainability of quality, human resources for national development". The result of the study revealed that proper management of student personnel services such as admission service among others, at the secondary school level has a positive influence on realization of sustainable future, vis-à-vis the attainment of school goals. Ehiane (2014) also supported this result when he investigated discipline and academic performance in selected secondary schools in Lagos, Nigeria and found out that effective school discipline has a great influence on students' behavior and thus affects their general academic performances, as well as the attainment of the general goal of the school system which is effective teaching and learning. Uwah and Mogbo (2013) supported this when they stated that guidance and counselling is one of the educational services that prompted the effectiveness of the educational system for goals attainment and guiding learners through the learning process. Zahyah, Yusuf and Muhajir (2016) in their study reported the existence of a relationship between guidance and counseling service and students' academic achievement among others. It implies that quality student personnel administration has a significant influence on the success of schools, which is akin to economic development.

The result of the last hypothesis revealed that there is a positive significant relationship between knowledge management and economic development of Cross River State. This result is collaborated by the findings of Bratti (2004) who designed a relationship model between economic growth and human capital accumulation. The results showed that there is positive direct relationship between education level and production level which according to him, leads to enhancing the consideration of knowledge as a production function in competitive business scenario. Bhullar and $\operatorname{Kaur}(2014)$ supported that knowledge and ideas have emerged as key drivers for the economic growth in current scenario. Kahreh (2011) in his study, asserted that the increased prominence of knowledge related economics from the beginning of the 1990s have coexisted with the development of the new view 


\section{International Journal of Engineering Applied Sciences and Technology, 2019 Vol. 4, Issue 5, ISSN No. 2455-2143, Pages 541-548 \\ Published Online September 2019 in IJEAST (http://www.ijeast.com)}

on business strategy that emphasizes resource efficiency rather than the generally accepted competitive forces. According to him, in the eeconomy era, for any country to achieve and sustain the competitive advantage, the implementation of strategic knowledge management (SKM) is undeniable. This implies that knowledge management is strongly related to economic development.

\section{RECOMMENDATIONS}

Based on the findings of the study, the following recommendations are made;

1. There should be effective provision and quality administration of school facilities in secondary schools within the state, to enhance the acquisition of practical skills, to boost economic development of the state.

2. Adequate training should be given to principals on high to design effective and quality student personnel services to effectuate teaching and learning atmosphere that would promote the attainment of the purpose of secondary education in the state.

3. There should be a re-design of the school experiences in line with the needs of the society, so as to ensure congruence between the knowledge acquired in school and the ones needed to the productivity of the state.

\section{CONCLUSION}

The effective attainment of the predetermined goals of the entire educational system means the achievement of the national goals of the country, which in turn, determines the growth and development of the entire country. Based on the findings of this study, it is concluded that quality secondary school facilities management, student personnel management and knowledge management have significant relationship with the economic development of Cross River State. This study may provide the basis for Government of Cross River State to increase facilities provision in schools, as well as train school administrators on contemporary models of student personnel management and curriculum designs in schools.

\section{REFERENCES}

1. Adelabu, E.I. (2013). Health education: Methods and planning. Lagos: Simarch Nigeria Ltd.

2. Ajayi I. A. (2007). Issues in School Management. Lagos: Bolabay publications .

3. Akpan, C. P., Okon, J. E. \& Ebuara, V. O. (Eds) (2015). Fundamentals of Educational Management. Calabar: University of Calabar Press.

4. Aloga, A. O. (2014). school plant administration: the challenges and transformation in learning and teaching in developing countries(a case study of secondary schools in Nigeria). Proceeding of the Global Summit on Education GSE (640643), Kuala Lumpur, MALAYSIA. Organized by WorldConferences.net

5. Amanchukwu, N \& Ololube, N (2015) Managing school plant for effective service delivery in public schools in Rivers State. Human Resource Management Research. 5(4),95-100.

6. Arong, F. E. \& Ogbadu, M. A. (2010). Major Causes of Declining Quality of Education inNigeria from Administrative Perspective: A Case Study of Dekina Local Government Area. Canadian social science, 6(3), 183198.

7. Asiabaka, I. (2008). The need for effective facilities management in school in Nigeria. New York Science Journal. Retrieved from: http:www. sciencepub.org.

8. Asiyai, R. (2012). Assessing school facilities in public secondary schools in Delta State, Nigeria. African Research Review: An International Multidisciplinary Journal, 6(2), 192-205.

9. Asuquo, P. N.(2009). Basic counseling Principles and Procedures for Teachers. Calabar: University of Calabar Press

10. Babalola, J. B.\& Isuku, E.(2008). Reducing poverty incidence in Nigeria. A paper presented at the International Conference for Nigeria Association For Educational Administration and Planning (NAEAP) at Sharaton Hotel, Abuja from $23^{\text {th }}-26^{\text {th }}$ September, 2012.

11. Bhullar, P. S \& Kaur, S. (2014). Analysis of role of knowledge management in economic growth. International Journal of Emerging Research in Management \&Technology, 3(5),29-33.

12. Bratti, M., Bucci,, A.and Moretti, I. (2004). Demographic Trends, Human Capital and economic Growth in Developing Countries: 


\section{International Journal of Engineering Applied Sciences and Technology, 2019 Vol. 4, Issue 5, ISSN No. 2455-2143, Pages 541-548 \\ Published Online September 2019 in IJEAST (http://www.ijeast.com)}

Theory and Evidence. Ancona: University of Ancona Press

13. Chidobi, R. U. (2015). Management of student personnel service in public secondary schools in Enugu Education Zone for sustainability of quality human resources for national development. International Journal of Scientific and Engineering Research, 6 (7),2103-2109.

14. Ehiane, O. S. (2014). Discipline and Academic Performance (A Study of Selected secondary Schools in Lagos, Nigeria). International Journal of Academic Research in Progressive Education and Development, 3(1), 181-194.

15. Ejionueme, L. K. (2010). Management of student personnel services in federal and state universities. An Unpublished Ph.D thesis submitted to Department of Educational Foundations, University of Nigeria, Nsukka

16. Federal Republic of Nigeria (2004). National Policy on Education. Lagos, NERDC press.

17. Gbenu, J. P. (2012).State of Nigerian Secondary Education and the Need for Quality Sustenance. Greener Journal of Educational Research, 2 (1), 007-012.

18. Jarboe, K. P.(2001). Knowledge management as an economic development strategy. Reviews of Economic Development Literature and Practice, 7, 1-36.

19. Kahreh, M. S. (2011). Economics of strategic knowledge management: A new model for assessment. International Journal of Trade, Economics and Finance, 2( 3),257-262.

20. Modo, F., Sanni, K., Uwah, C. \& Mogbo, I. (2013). Guidance and Counseling Services in Secondary School as Coping Strategy for Improved Academic Performance of Students in Akwa Ibom State, Nigeria. In Journal of Research on Humanities and Social Sciences, 3 (4), pp.43-47.

21. Ogbuji, J.E. (2009). Evaluation of student personnel services in secondary schools in Cross River State. An Unpublished Ph.D thesis submitted to Educational Foundations, University of Nigeria, Nsukka.

22. Okon, E. J. (2004). Understanding Administrative Behaviour in Educational Organizations. Calabar. Ultimate Index.

23. Olaniyan, 0 \& Israel, A. (2013). Effect of inadequate school plant on academic performance of Nigerian Secondary School students. International Journal of Humanities and management science, $l(3 j$ 198-201.
24. Olaniyan, 0. \& Israel, A. (2013). Effect of inadequate school plant on academic performance of Nigerian Secondary School students. International Journal of Humanities and management science, l(3j 198-201.

25. Olaniyonu, S. O. A., Adekoya, S. O. A. and Gbenu, J. P. (2008). Fundamentals of educational planning (ed). Lagos: Oshidex printing press.

26. Oyesola, G. O. (2007). Planning Education Building and facilities. Alphabetic List of Journal. Articles Ilorin. Retrieved from: http://www.ijeunilorin.net

27. Sani, D.M. (2007). Relationship among School Plant Construction, Utilization, Maintenance and School Effectiveness in Kebbi State Secondary Schools, Nigeria.Unpublished Ph.D. Dissertation, University of Ilorin, Nigeria.

28. Williams, A. (2004). Shaping a New Vision and Action for a More Functional and Qualitative Education in Lagos State. A paper presented at Lagos State Education Summit held in Ikeja and organized by Lagos State Government in 2004.

29. Zahyah, B. H., Yusuf, S. \& Muhajor, B. T. (2016). Modeling the nexus between students' personnel services and academic achievement in secondary schools. A Partial Least Square (PLS) approach. International Journal of Advances in management and economics, 5(2), 82-93. 